\title{
A clinical study of association of maternal height and estimated foetal weight on mode of delivery
}

\author{
Anup Ramrao Patil*, Manjusha Shailesh Agrawal, Deepti Sandeep Shrivastava
}

Department of Obstetric and Gynecology, Jawaharlal Nehru Medical College, Sawangi (M), Wardha, India

Received: 11 May 2015

Accepted: 06 June 2015

\author{
*Correspondence: \\ Dr. Anup Ramrao Patil, \\ E-mail: anuppatil68@yahoo.in
}

Copyright: () the author(s), publisher and licensee Medip Academy. This is an open-access article distributed under the terms of the Creative Commons Attribution Non-Commercial License, which permits unrestricted non-commercial use, distribution, and reproduction in any medium, provided the original work is properly cited.

\begin{abstract}
Background: Maternal height and antenatal estimated fetal weight can affect mode of delivery. The aims and objective of this study were to study the association between the mode of delivery and maternal height and estimated foetal weight.

Methods: 240 full term primigravida women without any obstetric and medical complications who were admitted in Acharya Vinoba Bhave Rural Hospital Wardha for delivery were randomly selected for study. After delivery 138 women who underwent caesarean delivery formed the study group and 102 women who underwent vaginal delivery formed control group. These two groups were compared for their maternal heights and antenatal estimated foetal weight (by Johnson's formula).

Results: In present study (1) Mean height of women in study group was $147 \mathrm{~cm}$ while that in control group was 155 $\mathrm{cm}$. (2) Out of 49 short statured women (height $\leq 145 \mathrm{~cm}) 47(95.91 \%)$ had emergency caesarean section and $2(4.08 \%)$ women were delivered vaginally. (3) Estimated foetal weight in study group was 2956 grams while that in control group was 2845 grams.

Conclusions: We conclude that short statured women with larger baby size has higher incidence of emergency caesarean delivery.
\end{abstract}

Keywords: Maternal height, Estimated foetal weight, Mode of delivery

\section{INTRODUCTION}

Pregnancy is one of the most critical and unique period in a woman's life cycle. It is regarded as 'welcome event' for successful womanhood ${ }^{1}$. Maternal and fetal mortality and morbidity are major health problems in developing countries like India. Throughout the world 2, 92,000 per year (800/day) women die as a result of preventable causes related to pregnancy and childbirth, of which $99 \%$ of all maternal mortality occurs in developing countries. $^{2}$

Numerous studies of healthy women from both affluent ${ }^{3-8}$ and less affluent countries ${ }^{9,10}$ have shown shorter maternal height and or larger newborn weight to be associated with increased delivery complications.
One of the important area in which obstetricians can contribute significantly is the care of pregnant women. And one of the primary goals of antenatal care is to identify those women with raised risks for problems during pregnancy or delivery, in order to ensure that precautionary measures are instituted wherever possible or more intensive medical care is to be provided. In developing countries like India, there is dearth of $\mathrm{MCH}$ care services. In rural areas, antenatal care is provided by Traditional Birth Attendants (TBA'S) and village health workers. For them, it is important to develop a simple risk indicator, which is easy to use and reliable. Maternal height is one of the simplest measurements to take into consideration. Usually a specified height is defined and below this attention to be paid to risk of CPD/contracted pelvis and for referral to higher centers, a good weight 
gain during pregnancy predicts a good baby weight. Weight gain especially in third trimester is associated with the weight of baby.

The present study was carried out to analyze the association of maternal height and estimated fetal weight of women on her obstetric performance in particular to emergency caesarean delivery.

\section{METHODS}

It was a cross sectional case-control study carried out in department of Obstetrics and Gynecology, Acharya Vinoba Bhave Rural Hospital, Sawangi Meghe, Wardha, Maharashtra from 2012-2014. 240 full term primigravida women without any obstetric and medical complications who were admitted for delivery were randomly selected for study.

\section{Inclusion criteria}

1) Primigravida patients.

2) Singleton vertex presentation.

3) Gestational age $\geq 37$ weeks.

4) Spontaneous onset of labour.

5) In early active phase of labour (75\% effaced cervix, at least $3 \mathrm{~cm}$ dilated).

\section{Exclusion criteria}

1) Pregnancy with medical or obstetric complications.

2) Non vertex presentation.

3) Those with fetal anomalies or fetal death.

4) Those were indicated for elective Caesarean Section.

After considering these inclusion and exclusion criteria 240 cases were selected out of which 138 cases who underwent emergency caesarean delivery formed the study group, and 102 women who gave birth vaginally formed the control group.

Fetal Weight Estimation done by Johnson's Formula-

Fetal weight $(\mathrm{g})=(\mathrm{McD}$ onald's measurement -13$) \times 155$ When the presenting part was at "minus" station

$=($ McDonald's measurement -12$) \times 155$ when presenting parts at "zero" station

$=($ McDonald's measurement -11$) \times 155$ when presenting part at plus station (McDonald's measurement - symphysiofundal height)

If woman weighed more than $91 \mathrm{~kg}, 1 \mathrm{~cm}$ was subtracted from fundal height. ${ }^{11-13}$

\section{RESULTS}

In present study out of 138 patients from study group, 15 $(10.87 \%)$ had height less than $140 \mathrm{~cm} .63(45.65 \%)$ patients had height in between 141-145 cm. 56 (40.58\%) had height $146-150$. Only $4(2.90 \%)$ patients had height above $150 \mathrm{~cm}$. In control group out of 102 patients, none of patient was belonging to less than $140 \mathrm{~cm} .7(6.86 \%)$ patients in between 141-145 cm. While $22(21.57 \%)$ patients in between 146-150 cm. 73(71.57\%) had height more than $150 \mathrm{~cm}$. The difference between study group and control group was found to be statistically significant $(\mathrm{P}<0.05)$. In the study group mean height was $147.74 \mathrm{~cm}$, where as in the controls it was 155.79 cms (Table 1).

Table 1: Distribution of patients according to height (cm) in both the groups.

\begin{tabular}{|c|c|c|c|c|c|c|}
\hline \multirow[t]{2}{*}{$\begin{array}{l}\text { Height } \\
(\mathrm{cm})\end{array}$} & \multicolumn{2}{|c|}{$\begin{array}{l}\text { Study Group } \\
(\mathrm{n}=138)\end{array}$} & \multicolumn{2}{|c|}{$\begin{array}{l}\text { Control } \\
\text { Group } \\
(n=102)\end{array}$} & \multirow[t]{2}{*}{$\begin{array}{l}\text { *2- } \\
\text { value }\end{array}$} & \multirow[t]{2}{*}{ p-value } \\
\hline & Cases & $\%$ & Cases & $\%$ & & \\
\hline $\begin{array}{l}138- \\
140 \\
\mathrm{cms}\end{array}$ & 15 & 10.87 & 0 & 0.00 & \multirow{6}{*}{108.9} & \multirow{6}{*}{$\begin{array}{l}\mathrm{p}<0.0001 \\
\mathrm{~S}\end{array}$} \\
\hline $\begin{array}{l}141- \\
145 \\
\mathrm{cms}\end{array}$ & 63 & 45.65 & 7 & 6.86 & & \\
\hline $\begin{array}{l}146- \\
150 \\
\mathrm{cms}\end{array}$ & 56 & 40.58 & 22 & 21.57 & & \\
\hline $\begin{array}{l}>150 \\
\mathrm{cms}\end{array}$ & 4 & 2.90 & 73 & 71.57 & & \\
\hline Total & 138 & 100 & 102 & 100 & & \\
\hline $\begin{array}{l}\text { Mean } \pm \\
\text { SD }\end{array}$ & \multicolumn{2}{|c|}{$147.74 \pm 3.88$} & \multicolumn{2}{|c|}{$155.79 \pm 5.63$} & & \\
\hline
\end{tabular}

In the present study (1) In maternal height range of $<145$ $\mathrm{cm}$ among 49 cases, 2(0.83\%) cases from control group delivered spontaneous vaginally, no case was undergone instrumental delivery, while $47(19.58 \%)$ cases were undergone caesarean delivery. (2) In maternal height range of 145 - $<150 \mathrm{~cm}$ among 66 cases, 8(3.33\%) cases was undergone spontaneous vaginal delivery, $1(0.42 \%)$ case was delivered by instrumental delivery while $57(23.75 \%)$ of cases were undergone caesarean delivery. (3) In maternal height range of $\geq 150 \mathrm{~cm}$ out of 125 cases, $85(35.42 \%)$ cases delivered spontaneous vaginally, $6(2.50 \%)$ were required instrumental delivery while $34(14.17 \%)$ cases were required caesarean delivery. Out of all 240 cases in maternal height range 95(39.58\%) cases were delivered spontaneous vaginally, $7(2.92 \%)$ cases were required instrumental delivery while $138(57.50 \%)$ cases required caesarean delivery. By using chi-square test $(99.17, \mathrm{p}$-value $=0.000, \mathrm{p}<0.05)$ the difference was found statistically significant (Table 2).

In the present study mean estimated weight in study group was 2956 grams, while in control group it was 2845 grams. By applying chi-square test the difference was found to be significant $(\mathrm{p}<0.05)$. Women with lesser height and larger baby are more likely to go for caesarean delivery (Table 3 ). 
Table 2: Maternal height and mode of delivery.

\begin{tabular}{|c|c|c|c|c|c|c|c|}
\hline \multirow{3}{*}{$\begin{array}{l}\text { Maternal } \\
\text { Height(cms) }\end{array}$} & \multicolumn{7}{|c|}{ Mode of delivery } \\
\hline & \multicolumn{2}{|c|}{$\begin{array}{l}\text { Spontaneous } \\
\text { vaginal delivery }\end{array}$} & \multicolumn{2}{|c|}{$\begin{array}{l}\text { Instrumental } \\
\text { Delivery }\end{array}$} & \multicolumn{2}{|c|}{$\begin{array}{l}\text { Caesarean } \\
\text { Delivery }\end{array}$} & \multirow{2}{*}{ Tota } \\
\hline & $\mathbf{n}$ & $\%$ & $\mathbf{N}$ & $\%$ & $\mathbf{n}$ & $\%$ & \\
\hline$\leq 145 \mathrm{~cm}$ & 2 & 0.83 & 0 & 0.00 & 47 & 19.58 & 49 \\
\hline$<150-145 \mathrm{~cm}$ & 8 & 3.33 & 1 & 0.42 & 57 & 23.75 & 66 \\
\hline$\geq 150 \mathrm{~cm}$ & 85 & 35.42 & 6 & 2.50 & 34 & 14.17 & 125 \\
\hline Total & 95 & 39.58 & 7 & 2.92 & 138 & 57.50 & 240 \\
\hline$\aleph 2$-value & \multicolumn{7}{|c|}{ 99.17, $\mathrm{p}$-value $=0.000, \mathrm{~S}, \mathrm{p}<0.05$} \\
\hline
\end{tabular}

Table 3: Distribution of patients according to estimated fetal weight in both the groups.

\begin{tabular}{|c|c|c|c|c|c|c|}
\hline \multirow{2}{*}{$\begin{array}{l}\text { Estimated Birth } \\
\text { Weight (gram) }\end{array}$} & \multicolumn{2}{|c|}{$\begin{array}{l}\text { Study Group } \\
(\mathbf{n}=\mathbf{1 3 8})\end{array}$} & \multicolumn{2}{|c|}{$\begin{array}{l}\text { Control Group } \\
(n=102)\end{array}$} & \multirow[t]{2}{*}{ «2-value } & \multirow[t]{2}{*}{ p-value } \\
\hline & Cases & $\%$ & Cases & $\%$ & & \\
\hline$<2.5 \mathrm{~kg}$ & 5 & 3.62 & 14 & 13.73 & \multirow{5}{*}{6.91} & \multirow{5}{*}{$\begin{array}{l}0.031 \\
S, \\
p<0.05\end{array}$} \\
\hline 2.5 to $3.5 \mathrm{~kg}$ & 129 & 93.48 & 87 & 85.29 & & \\
\hline$>3.5 \mathrm{~kg}$ & 4 & 2.90 & 1 & 0.98 & & \\
\hline Total & 138 & 100 & 102 & 100 & & \\
\hline Mean \pm SD & \multicolumn{2}{|c|}{$2956.59 \pm 293.80$} & \multicolumn{2}{|c|}{$2845.09 \pm 285.64$} & & \\
\hline
\end{tabular}

Table 4: Maternal height and estimated fetal weight.

\begin{tabular}{|c|c|c|c|c|c|c|c|c|}
\hline \multirow{3}{*}{$\begin{array}{l}\text { Maternal } \\
\text { Height } \\
\text { (cms) }\end{array}$} & \multicolumn{6}{|c|}{ Estimated Birth weight in kg } & \multicolumn{2}{|l|}{ Total } \\
\hline & \multicolumn{2}{|l|}{$<2.5 \mathrm{~kg}$} & \multicolumn{2}{|c|}{2.5 to $3.5 \mathrm{~kg}$} & \multicolumn{2}{|l|}{$>3.5 \mathrm{~kg}$} & \multirow[b]{2}{*}{$\begin{array}{l}\text { Study } \\
\text { group }\end{array}$} & \multirow[b]{2}{*}{ Controls } \\
\hline & $\begin{array}{l}\text { Study } \\
\text { group }\end{array}$ & Control & $\begin{array}{l}\text { Study } \\
\text { group }\end{array}$ & Control & $\begin{array}{l}\text { Study } \\
\text { group }\end{array}$ & Control & & \\
\hline$<145 \mathrm{~cm}$ & $3(2.17 \%)$ & $1(0.98 \%)$ & $\begin{array}{l}44 \\
(31.88 \%)\end{array}$ & $1(0.98 \%)$ & $0(0 \%)$ & $0(0 \%)$ & $\begin{array}{l}47 \\
(34.06 \%)\end{array}$ & $2(1.96 \%)$ \\
\hline $\begin{array}{l}<150-145 \\
\mathrm{~cm}\end{array}$ & $2(1.45 \%)$ & $1(0.98 \%)$ & $\begin{array}{l}53 \\
(38.41 \%)\end{array}$ & $8(7.84 \%)$ & $2(1.45 \%)$ & $0(0 \%)$ & $\begin{array}{l}57 \\
(41.30 \%)\end{array}$ & $9(8.82 \%)$ \\
\hline$\geq 150 \mathrm{~cm}$ & $0(0 \%)$ & $\begin{array}{l}12 \\
(11.76 \%)\end{array}$ & $\begin{array}{l}32 \\
(23.19 \%)\end{array}$ & $\begin{array}{l}78 \\
(76.47 \%)\end{array}$ & $2(1.45 \%)$ & $1(0.98 \%)$ & $\begin{array}{l}34 \\
(24.64 \%)\end{array}$ & $\begin{array}{l}91 \\
(89.22 \%)\end{array}$ \\
\hline Total & $5(2.08 \%)$ & $\begin{array}{l}14 \\
(13.73 \%)\end{array}$ & $\begin{array}{l}129 \\
(53.75 \%)\end{array}$ & $\begin{array}{l}87 \\
(85.29 \%)\end{array}$ & $\begin{array}{l}4 \\
(2.90 \%)\end{array}$ & $1(0.98 \%)$ & $\begin{array}{l}138 \\
(57.50 \%)\end{array}$ & $\begin{array}{l}102 \\
(100 \%)\end{array}$ \\
\hline$\aleph 2$-value & 8.97 & & 75.91 & & 0.75 & & 82.05 & \\
\hline p-value & $0.01, \mathrm{~S}$ & & $\mathrm{p}<0.0001$ & & $0.38, \mathrm{NS}, \mathrm{p}$ & $>0.05$ & $\mathrm{p}<0.0001, \mathrm{~S}$ & \\
\hline
\end{tabular}

In the present study in higher maternal height range $(>150$ $\mathrm{cm})$ and lower estimated fetal weight range $(<2.5 \mathrm{~kg})$ almost all (12 out of 12) babies are delivered vaginally. Similarly in lower maternal height range $(<145 \mathrm{~cm})$ and higher estimated fetal weight range $(2.5-3.5 \mathrm{~kg})$, almost all (44 out of 45) babies are delivered by caesarean section (Table 4).

According to table 2, 3 and 4; we can conclude that cases with maternal height range $<150 \mathrm{~cm}$ and estimated fetal weight range $\geq 3.5 \mathrm{~kg}$ (corresponding to $34-35 \mathrm{~cm}$ of symphysio-fundal height) should be referred to higher hospitals without delay.
In present study in the study group the incidence of caesarean delivery in women with height $145 \mathrm{~cm}$ was $32.5 \%$. Whereas those with height more than $145 \mathrm{~cm}$ was $25 \%$ (Table 5).

Table 5: Height and emergency caesarean delivery in study group.

\begin{tabular}{|lll|}
\hline Height in cm & Cases & Percentage \\
\hline$<145$ & 78 & $32.5 \%$ (of all 240 cases) \\
\hline$>145$ & 60 & $25 \%$ (of all 240 cases) \\
\hline
\end{tabular}


Table 6: Comparative figures.

\begin{tabular}{|lllllll|}
\hline $\begin{array}{l}\text { Caesarean } \\
\text { Section }\end{array}$ & $\begin{array}{c}\text { Karltreinder } \\
\text { 15 }\end{array}$ & $\begin{array}{l}\text { Desai } \\
\text { et al }\end{array}$ & $\begin{array}{l}\text { Parsons } \\
\text { et al }^{8}\end{array}$ & $\begin{array}{l}\text { Tripathi } \\
\text { m et al }^{18}\end{array}$ & $\begin{array}{l}\text { Nourah } \\
\text { et a }\left.\right|^{19}\end{array}$ & $\begin{array}{l}\text { Present } \\
\text { study }\end{array}$ \\
\hline
\end{tabular}

\section{DISCUSSION}

In the present study incidence of emergency caesarean delivery in short mothers was $32.5 \%$ while that in women with height more than $145 \mathrm{~cm}$ was $25 \%$. Thus women who are less than or equal to $145 \mathrm{~cm}$ have higher risk of emergency caesarean delivery when compared to women of more than $145 \mathrm{~cm}$. In a study by Kathleen et al., ${ }^{14}$ women of $146 \mathrm{~cm}$ height (-1 SD) relative to another of $160 \mathrm{~cm}(+1 \mathrm{SD})$ had a 2.5 times of higher risk of emergency caesarean delivery. The independent risk for emergency caesarean delivery occurring for a healthy, nulliparous women with no obstetric or clinical pathology but of $146 \mathrm{~cm}(-1$ SD) was 2.5 times higher relative to women of 166 (+1 SD) in height was clearly established in their study. Thus women of height $<145 \mathrm{~cm}$ form a risk group who needs constant vigilance during their labour for signs of CPD and early referral to higher centres in the event of prolonged labour was needed to avoid disastrous labour outcome.

In the present study, incidence of emergency caesarean delivery in short mothers was $32.5 \%$. The above table shows the comparative figures of caesarean delivery. Though the present study show higher incidence of caesarean section as compared to Karltreinder, ${ }^{15}$ but results of the present series were in near comparison with that of Desai et al. ${ }^{16}$ (Table 6).

Baird ${ }^{17}$ postulates that every woman has a potential height. This is decided by factors like race and genetics. However, there occur certain insults that are entirely influential, if it is so during her period of development. As a result of which she becomes short stature.

In the present study according to table no. 2 we can conclude that in height range of $<145 \mathrm{~cm}$ almost all cases were delivered by caesarean section, in height range of $145-<150 \mathrm{~cm}$ also rate of caesarean section was very high, thereafter rate of caesarean section decreased and rate of normal delivery increased. According to table, cases with height $<150$ was the target population on which we have to pay all attention to prevent neglected obstructed labour and undue maternal morbidity.

In the present study mean estimated weight in study group was 2956 grams while in control group it was 2845 grams. Women with lesser height and larger baby were more likely to go for caesarean delivery.Karltreinder ${ }^{15}$ mentions that taller women tend to produce heavier children in contrast to the shorter women who tend to produce lighter ones.

\section{CONCLUSIONS}

We concluded that short statured women with larger baby size had higher incidence of emergency caesarean delivery. In present study (1) Mean height of women in study group was $147 \mathrm{~cm}$ while that in control group was $155 \mathrm{~cm}$. (2) Out of 49 short statured women (height $\leq 145$ cm) $47(95.91 \%)$ had emergency caesarean section and $2(4.08 \%)$ women were delivered vaginally. (Table 2) (3) Estimated foetal weight in study group was 2956 grams while that in control group was 2845 grams.

\section{ACKNOWLEDGEMENTS}

I am deeply indebted to my mentor and guide, Dr. Manjusha S. Agrawal, for her excellent guidance, constant appraisal and motivation. I owe a great deal of respect, gratitude and indebtedness towards Dr. Deepti Shrivastava Professor and head, Dept. of Obstetrics \& Gynecology for her constant help and valuable suggestion with timely motivation.

Funding: No funding sources

Conflict of interest: None declared

Ethical approval: The study was approved by the Institutional Ethics Committee

\section{REFERENCES}

1. Vijayalaxmi KG, Urooj A. Influence of maternal factors on mode of delivery and birth weight in urban pregnant women. J Hum Ecol. 2009;25(2):133-6.

2. AbouZahr C, Royston E, eds. In: Maternal Mortality: a fact book, Geneva: WHO, N0 348, Update May 2014.

3. Thompson AM. Maternal stature and reproductive efficiency. Eugenics Review. 1959;51:157-62.

4. Bernard RM. The shape and size of female pelvis. Edin Med J. 1952:59:1-15.

5. James DK, Chiswick ML. Kielland's: role of ante natal factors in prediction of use BMJ. 1979;1:10-1.

6. Dougherty CRS, Jones AD. Obstetric management and out come related to maternal characteristics. Am J Obstet Gynecol. 1988:158:470-4.

7. Thomson M, Hanley J. Factors predisposing to difficult labour in primiparas. Am J Obstet Gynecol. 1988;158:1074-8.

8. Parsons MT, Winegar A, Siefert L, Spellacy WN. Pregnancy out comes in short women J Reprod Med. 1989:34:357-61.

9. Tsu VD. Matemal height and age: risk factors for cephalo pelvic disproportion in Zimbabwe. Int J Epi. 1992;21:941-6. 
10. Harrison KA. Predicting trends in operative delivery for cephalopelvic disproportion in Africa. Lancet. 1990;335:861.

11. Johnson RW. Calculations in estimating fetal weight. Am J Obstet Gynecol. 1957;74:929.

12. Loeffler FE. Clinical fetal weight prediction. J Obstet Gynecol Br Commonow. 1967;74:675-7.

13. Ong HC, Sen DK. Clinical estimation of fetal weight. Am J Obstet Gynecol. 1972;112:877-80.

14. Merchant KM, Villar J, Kestler E. Maternal height and newborn size relative to risk of intrapartum caesarean delivery and perinatal distress. British Journal of Obstetrics and Gynecology. 2001;108:689-96.

15. Frank K. "Effect - Height- Weight- PregnancyNewborn", Monogram, 1963.
16. Desai P, Hazra M, Trivedi LB. Pregnancy outcome in short statured women. J Indian Med Asso. 1989;32-s4.

17. Baird D. Environmental and Obstetrical factors in prematurity with special reference to experience in Aberdeen. WHO Tech Rep Ser. 1962;26:291-5.

18. Tripathi M, Chaudhary P. Fetomaternal outcome in relation to maternal height among primigravidas. Journal of Gandaki Medical College - Nepal. 2009;2(4):18-23.

19. Nourah H. Al Qahtani, Salha Al Ganmi, Asma Badran. The risk of cesarean delivery in short Saudi women. International journal of clinical Medicine. 2012;3:238-41.

Cite this article as: Patil AR, Agrawal MS, Shrivastava DS. A clinical study of association of maternal height and estimated foetal weight on mode of delivery. Int J Reprod Contracept Obstet Gynecol 2015;4:1020-4. 